\title{
Understanding the aspirations of ultra-poor women in Bangladesh can enhance wellbeing and target development efforts
}

\author{
Lynn McIntyre · Krista Rondeau
}

\begin{abstract}
Much development research is focused on deprivations as well as contextual factors that limit individuals' freedoms and choices to lead the lives they value; however, less attention is paid to "the ends" or "the good life" and how these can inform development efforts. This paper examines the aspirations of 43 ultra-poor female heads of household living in urban and rural Bangladesh within the context of wellbeing, i.e., the lives they value, in order to better understand how they could be assisted through development efforts. All women in our study articulated conceptions of personal wellbeing that were linked to their children and with the aim of conducting themselves as good mothers and honourable women. Physical and emotional hardship and the sacrifice of personal aspirations, happiness, nutrition, and health were required to establish children, who might in turn care for them in their old age; still, achieving these modest goals was difficult and resulted in constant worry or "tension." Given the life these women value, social programs and policies that aim to support ultra-poor women who have children must consider how they can provide assistance that will benefit women directly without asking them to withhold assistance from their children.
\end{abstract}

Keywords: wellbeing, well-being, capability approach, Bangladesh, ultra-poor women, whole person development

\section{Introduction}

Human development is defined as "an expansion of real freedoms of people to pursue lives that they value and have reason to value" (Klugman, 2010, p. 85). Based on Sen's capability approach (cf. Robeyns, 2005), much development research is focused on deprivations such as lack of income, shelter, health, education, as well as contextual factors that ultimately limit individuals' freedoms and choices-capabilities-to lead the lives they have reason to value (Camfield, Crivello, \& Woodhead, 2009; Clark, 2002; McGregor, 2004). Development theorists such as Nussbaum and Sen, who favour this approach, argue that focusing on capabilities avoids the paternalistic imposition of any particular notion of "the good life" (Robeyns, 2006, p. 353) and allows for a range of possible ways of living (Robeyns, 2006). Nonetheless, Nussbaum (2000) has called for a consideration of the functioning of each person - "the principle of each person as end" (p. 56). Indeed, by Sen's (1999) own assertion, "it is the ends that make development important [emphasis added]" (p. 3). Thus, research that focuses on the nature of the good life and ends may inform development efforts that aim to improve wellbeing, in particular for the least well-off (Nussbaum, 2000, p. 56). 
Values and goals, i.e., aspirations, are a language used to discuss wellbeing, including subjective perspectives and material/objective indicators (Appadurai, 2004; Camfield et al., 2009; White, 2010a) and these terms provide an articulation of what the capability literature refers to as the good life or the ends. ${ }^{1}$ Wellbeing considers what people have or do not have, what people can do or cannot do, what people think or feel (Wellbeing Research in Developing Countries, n.d.), and "it places the person, in their relationships and surroundings, at the centre" by considering what people value and aspire to (Camfield et al., 2009, p. 8). Typically, multidimensional wellbeing research, while exploring its objective, subjective, and relationship dimensions, continues to focus primarily on "how people think and feel about what they have and do" (McGregor, McKay, \& Velazco, 2007, pp. 110-111), rather than on the things they aspire to or value (Camfield et al., 2009). For example, Biswas-Diener and Diener (2001) measured the life satisfaction and subjective wellbeing of 84 slum dwellers in Calcutta and found that while participants found some satisfaction with social relationships, overall they were neutral or slightly dissatisfied, which "suggests that poverty is a condition to which people do not completely adapt" (p. 342). In an attempt to generate a multidimensional understanding of people's lives that might inform development efforts, international development and poverty researchers have made concerted efforts to include subjective experiences and meanings of wellbeing as aspirational ends (Camfield et al., 2009).

Building on a long history of wellbeing research (Camfield et al., 2009), the Economic and Social Research Council Research Group on Wellbeing in Developing Countries (ESRC-WeD) has sought to enhance development efforts through a theoretical and empirical focus on wellbeing that considers both objective and subjective local perspectives of wellbeing that are embedded within the environment in which individuals live (cf. Gough \& McGregor, 2007). ${ }^{2}$ McGregor (2004) argues that alongside deprivations, poor men, women, and children are "active agents trying to construct a good life for themselves and others close to them" (p. 346), and thus it is important to understand "the local vision of what must be done to achieve wellbeing in specific contexts" (Gough \& McGregor, 2007, p. 15). Thus, classic development initiatives (e.g., education programs, microcredit, etc.) that view ultra-poor women (those living on less than \$1.25 USD per day) as natural candidates because they lack income, food security, health, and education (see Alkire, 2010) may fail because they do not account for women's personal aspirations and conceptualization of wellbeing within the context of their daily lives (Gough, 2004; Ibrahim, 2011; McGregor, 2004).

\subsection{Whole person development}

The women whose experiences form the basis of this research represent a group that is especially vulnerable due to gender inequalities and poverty (Commission on Social Determinants of Health, 2008; Moss, 2002), and therefore feature prominently in international development initiatives, such as the Millennium Development Goals. Nonetheless, they are still not being reached in any significant way by current social programs and policies in Bangladesh (Ahmed, Petzold, Kabir, \& Tomson, 2006; Halder \& Mosley, 2004; Kabeer, 2004; Matin, Sulaiman, \& Rabbani, 2008; Rahman \& Hossain, 1995; Walker \& Matin, 2006). ${ }^{3}$ We contend that

\footnotetext{
${ }^{1}$ While it is beyond the scope of this paper to provide a detailed review of capabilities, functionings, aspirations, and wellbeing, this can be found in Ibrahim (2011).

${ }^{2}$ Further information on the Wellbeing in Developing Countries Research can be found at http://www.welldev.org.uk/research/research.htm.

${ }^{3}$ In fact, the women in our study and local NGO workers were largely unaware of each other, especially in urban settings. Further details can be found in McIntyre, Rondeau, Kirkpatrick, Hatfield, Islam, \& Huda (2011).
} 
in order to leverage improvements from current development programming and policy and ultimately improve the lives of the women who are the intended recipients, an understanding of the population for whom assistance is sought is vital. Nussbaum (2000) has similarly suggested that consideration of "the special problems women face because of sex" is required to confront issues of poverty and development (p. 4). Through the capability approach, Sen has challenged development agencies, governments, practitioners, and policymakers to move beyond utilitarian individualism and consider the role of social capital and social infrastructures (e.g., education, transportation, public health) in enabling self-realization (Douglas \& Ney, 1998). More recently, the wellbeing literature has called for an extension of the capability approach, i.e., a "theory of the person" (Douglas \& Ney, 1998, p. 79), where people are seen as both "social beings" and "whole persons" (Gough \& McGregor, 2007, p. 324). Enabling people to achieve wellbeing becomes a key humanitarian ingredient to development by reconciling macro-level development tools and instruments with local understanding of poverty and wellbeing.

A discussion of aspirations and wellbeing provides an opportunity to recognize women's intrinsic value as individuals since: "it is through the capacity to aspire that the exercises of voices by the poor will be extended" (Appadurai, 2004, p. 83). Further, this discussion can identify key leverage points that can then be used to make small but meaningful adjustments to services, programs, and policies for ultra-poor women. In other words, attending to women as whole persons - as "ends in their own right" (Nussbaum, 2000, p. 6) -through "a strategy that proposes small adjustments to services, programs and policies based on leverage points identified through in-depth narratives...with vulnerable populations." (McIntyre et al., 2011, p. 975). We have termed this approach Whole Person Development (McIntyre et al., 2011) and suggest that targeting numerous leverage points simultaneously could lead to sustainable improvements in the lives of the women that enable a life worth living.

\subsection{Purpose of this study}

Inspired by urgings to consider a wider range of dimensions regarding poverty for improved academic understanding and policy thinking (Ibrahim, 2011; McGregor et al., 2007, p. 108), we wondered whether the theoretical orientation of wellbeing research and a consideration of the Whole Person Development approach would permit a more textured understanding of the development needs of ultra-poor women who are heads of household in Bangladesh (commonly thought to be "unreachable") through a deeper examination of their aspirations. Individuals are best able to speak to aspirations and conceptualizations of wellbeing (Chambers, 1997) by providing an account of "life as seen from below" (Wikan, 1985, p. 8; see also Ibrahim, 2011). Indeed, ethnography and grounded methodologies have been proposed as important ways to understand "people-centred 'aspirations-enhancing' development policy" (Ibrahim, 2011, p. 3) and an ideal way of determining wellbeing (Camfield et al., 2009; see also Geertz, 1973). Using narratives from an ethnographic study of 43 ultra-poor female heads of household living in urban and rural Bangladesh (McIntyre et al., 2011), the purpose of this paper is to examine ultra-poor women's conceptualizations of wellbeing in order to better understand how women could be assisted through development efforts.

\section{Research methods}

Ethical approval for this study was received from the Conjoint Health Research Ethics Board at the University of Calgary and the Bangladesh Medical Research Council. The study's recruitment and data collection methods have been described in detail in a previous 
publication (McIntyre et al., 2011). Briefly, this study comprised 43 ultra-poor women heads of household, defined as the sole financial earner in the household regardless of the presence of other adults. All participants had dependent children and some $(n=11)$ supported dependent, often disabled or infirm, husbands. Participants were first selected on the basis of occupation (garment work, rural or urban petty trading, subsistence agriculture, or indigenous day labour). Once satisfying the financial and dependent children criteria for inclusion described above, purposive sampling sought women of different age groups who had been heads of household for different lengths of time and who were migrants or long-time residents of the area. Armed with these criteria, trained recruiters sought out potential participants by travelling on foot and visiting their homes during off-work hours. BRAC (a local nongovernmental organization) community health workers recruited garment workers and urban traders; two study collaborators recruited rural traders and agriculturalists; and two indigenous persons recruited Garo informal workers. ${ }^{4}$ Participants included 10 garment workers and 7 petty traders living in Korail Basti (a Dhaka slum), 5 petty traders and 11 agricultural workers from rural Ghorasal, and 10 indigenous Garo women who were precariously employed in the informal sector, living in the remote villages of Askipara and Rangapara near the Indian border. This diverse sample was chosen so as to generate "a rich variation in the experience of poverty" (Biswas-Diener \& Diener, 2001, p. 333).

In January and February, 2008, each woman participated in a single individual face-to-face semi-structured ethnographic interview regarding the daily food routine. Women were asked to describe a typical day, from the time they woke up until they went to bed. They were also asked to reflect on what they did in an average day to manage food and meals for themselves and their families, including strategies for acquiring food, sources of food, meal planning, food preparation, and consumption practices, and what assistance would be required to help them do so. Probes were used as required for clarification or additional information. Interviews were held in a private location with female interviewers and trained translators, and the interviews were digitally audio-recorded. Additional sociodemographic and anthropometric data were collected, and a summary of these results can be found in Table 1 (below). Interviews underwent multi-stage translation. Briefly, the recorded interviews were translated into English by bilingual Bangladeshi university instructors and a Garo translator. Translated texts were then checked for accuracy against audio-recordings by a bilingual Bangladeshi-Canadian student. A complete description of the translation process can be found in McIntyre et al. (2011).

\subsection{Analysis}

The analytical framework used for this study was conventional qualitative content analysis, an inductive strategy where:

categories and names for categories ... flow from the data [and] researchers immerse themselves in the data to allow new insights to emerge. ... Knowledge generated ... is based on participants' unique perspectives and grounded in the actual data. (Hsieh \& Shannon, 2005, pp. 1279-1280; see also Graneheim \& Lundman, 2004).

\footnotetext{
${ }^{4}$ See Bal (2007a; 2007b) for a socio-cultural and politico-historical overview of the Garo.
} 
Table 1. Selected sociodemographic characteristics of participants, $n=43$

\begin{tabular}{|c|c|}
\hline Variable & Description \\
\hline Occupational group & $n$ \\
\hline Garment worker (GW) & 10 \\
\hline Rural petty trader (RPT) & 5 \\
\hline Urban petty trader (UPT) & 7 \\
\hline Subsistence agriculturalist (SA) & 11 \\
\hline Informal worker (Garo) & 10 \\
\hline Head of household status & $n(\%)$ \\
\hline Abandoned & $15(34.9)$ \\
\hline Divorced & $2(4.7)$ \\
\hline Widow & $13(30.2)$ \\
\hline Disabled husband & $11(25.6)$ \\
\hline Left husband & $2(4.7)$ \\
\hline Time as head of householda & Years \\
\hline Range & $0.5-10$ \\
\hline Average & 4.9 \\
\hline Age $^{a}$ & Years \\
\hline Range & $20-65$ \\
\hline Average age & 34.4 \\
\hline Religion & $n(\%)$ \\
\hline Muslim & $30(69.8)$ \\
\hline Hindu & $3(7.0)$ \\
\hline Christian & $10(23.3)$ \\
\hline Education & $n(\%)$ \\
\hline None & $30(69.8)$ \\
\hline Some (unspecified) & $3(7.0)$ \\
\hline Primary Level (Class 1-5) & $7(16.3)$ \\
\hline Secondary Level (Class 6-10) & $3(7.0)$ \\
\hline Home ownership & $n(\%)$ \\
\hline Tenant & $21(48.8)$ \\
\hline Ownera & $22(51.1)$ \\
\hline Rent $^{\mathbf{b}}$ & taka/month \\
\hline Range & $250-1000$ \\
\hline Average & 623 \\
\hline Garden & $n$ \\
\hline For domestic consumption & 8 \\
\hline For sale & 4 \\
\hline Animals & $n$ \\
\hline For domestic consumption & 0 \\
\hline For sale & 16 \\
\hline Children & Years \\
\hline Average age of childrenc & 10.5 \\
\hline Average number, range (GW, RPT, UPT, SA) & $2.2,1-4$ \\
\hline Average number, range (Garo) & $4.4,1-9$ \\
\hline Average number, range (all) & $2.7,1-9$ \\
\hline $\begin{array}{l}\text { Number of households where children were unable to attend school } \\
\text { due to financial reasons }\end{array}$ & $\mathrm{n}=19(44.2 \%)$ \\
\hline
\end{tabular}


The initial analysis of women's narratives revealed their typical day to be repetitive and demanding, characterized by domestic chores, childcare, employment and overtime, and sleep:

Getting up from bed I have to clean up my dishes, sweep my floor. After that I have to cook and feed my kid. Then I have to go to my shop and sit there ... Coming home [at 10pm] I feed my children. I also take some food and go to bed to take rest. (Chandra, urban trader)

Seeking to determine how their typical day extends to the notion of wellbeing and a good life, fragments of text where women mentioned hopes, dreams, "feeling good," aspirations, and future wellbeing were sought and analyzed to reveal a story that went beyond a discussion of their immediate survival needs (see McIntyre et al., 2011). The most vulnerable are typically without voice and representation, and are often unable to provide an answer when asked directly what specific type of assistance is needed and how it should be provided (and this was the case for the women in our study). This indirect method of determining conceptions of wellbeing is helpful in avoiding some of the problems of direct probing on wellbeing using open- or closed-questioning, e.g., the inability to imagine the good life, restricting responses to predetermined categories at the expense of other potentially important information, the advancement of political interests, a desire to please the researcher or avoid embarrassment and distress, etc. (see Clark, 2002, pp. 102-104). This method also allows for the emergence of culturally embedded indicators of wellbeing that may not be apparent with the use of a research instrument designed from a theoretical tradition that "may be, in some respects, quite the wrong ones for the assessment [of the lives of women]" (Nussbaum, 2000, pp. 39-40). Coding was conducted using the qualitative research software NVivo (QSR International, 2010) alongside analytical techniques used in conventional qualitative content analysis such as immersion/crystallization (Borkan, 1999), comparison within and across cases (Bryman, 2004), reflectivity (Ben-Ari \& Enosh, 2010), thematic network analysis (Attride-Stirling, 2001), and peer debriefing (Lincoln \& Guba, 1985). In order to ensure the credibility of our results (Borkan, 1999; Bryman, 2004; Hsieh \& Shannon, 2005; Silverman, 2006), results were shared with 39 of 43 participants in March, 2009 through six returning results sessions. In addition to sharing results, these sessions allowed the research team to ascertain whether the participants were in agreement with the findings. Fieldnotes were taken and these complemented the textual data from interview transcripts.

\section{Findings}

We have previously shown how qualitative inquiry about the daily food routine can provide insight into the lived experience of poverty and food insecurity, including an understanding of contextual constraints on women's ability to earn an income and care for their family (e.g., gendered norms, lack of education, corruption, limited access to healthcare, etc.) (McIntyre et al., 2011). In the following section, we extend women's narrative of survival and chronicle their aspirations for wellbeing, revealing that these are primarily constructed through a daily and constant preoccupation with the establishment of their children alongside the desire to maintain their reputation and their honour as mother and woman. These aspirations represented hope for future wellbeing, care, and survival that women believed was within their limited realm of influence and capabilities. However, women faced difficulty in achieving even these modest aspirations and thus expressed constant worry or "tension" regarding their inability to achieve even meagre elements of wellbeing. We explore and contrast these constructs below. 


\subsection{Women's aspirations and construction of wellbeing}

Overall, women's aspirations as persons were extremely limited. Certainly, all women sought access to basic needs, such as shelter, food, and healthcare. Some women were able to evoke dreams such as remarriage or the return of their estranged husband ("My husband hasn't divorced me yet; he may accept me anytime again. I hope for that; I have no other intention." [Komali, garment worker]); the ability to adequately provide for their families and save for the future; or simply "to sleep soundly on a comfortable bed" (Joyeeta, rural trader). However, most women were unable to articulate distinct, personal aspirations and frequently described feeling hopeless and without a future of their own: "I had hope for [the] future but now I am passing my days somehow" (Dali, agriculturalist). While women's hopelessness and lack of aspirations were poignant, and certainly a reflection of the deep vulnerability in which they live (McIntyre et al., 2011), further exploration of the contention that the lives of people who are poor would be unbearable if they were unable to articulate and achieve even a modest conception of wellbeing (e.g., Gough \& McGregor, 2007; Kahneman, Diener, \& Schwarz, 1999) was warranted.

\subsubsection{Social and spiritual wellbeing}

White (2010b) notes that religion and spirituality can offer social rehabilitation to those experiencing loss of social status. Indeed, women described a good life as one where they met social and spiritual expectations to be a good mother and an honourable woman through hard work and self-sacrifice: “I don't see [any dream] about me; I [dream] about my child. Whatever dream I had about me has been demolished. ... I have only one dream; that is, I will bring up my kid properly" (Chumi, garment worker). Thus, women censored personal dreams like remarriage so that they could be respected by their children, the community, and for many, Allah or God. This self-censoring is in line with the expectation that women support the needs of others over their own (Nussbaum, 2000). Komali (garment worker), who has a one-year old son, explained:

I won't marry again because if I marry again people in the society will speak ill of me. I have a child; when he will grow up he will not look at me with honour, will not tolerate me; he'll think badly of me.

Chira (urban trader) proffered, "I have only one daughter, what will I do? I have to live only for her. Otherwise, I could have got married again; then I could have got a family life again." Unlike the married adolescent girls studied by Rashid (2006), who expressed that children were a way to ensure economic security even after a marriage breakdown, the women in this study did not report receiving any kind of support, financial or otherwise, from their children's fathers and the responsibility for their children's wellbeing appeared to rest entirely on them. Most of all, women feared they would be required to abandon their children if they were to remarry, which was based on the expectation that husbands would not want to take care of children who were not their own. The extent of this practice in Bangladesh, and among the ultra-poor in particular, is unknown, as we could not identify documentation of this practice in the literature; however, all of the women in this study who discussed remarriage were fearful of having to abandon their children and the impact it would have on their children's wellbeing.

\subsubsection{Achieving wellbeing through their children}

Women's aspirations were closely bound to their children: "I am a simple person; I work to get my meal. You give my kids knowledge, wisdom, you give me good days in future" (Panchali, 
agriculturalist). Women reported "feeling good" and being "without grief" when they were able to earn enough money to provide adequate and appropriate food to their children and enjoy a meal together. Dipika (Garo) explained, "I am poor, but I feel good [when we eat together]." And Bhavani (agriculturalist) explained:

As I work in rich people's house I can watch what the rich people feed their children. I wish I could do that! This is my dream. I also want to make my children study in a good school. This is all that I want. My children are the centre of all my dreams. I don't want anything else. I don't want to wear costly sari [traditional clothing] [or] costly shoes. I don't want to eat good food. I just want to give my children good education.

Thus, women were driven in their typical day by a strong desire to "establish" their children by providing adequate food and clothing, attending to their education and healthcare needs, and securing dowry or the equivalent, and they endured arduous employment as well as selfsacrifice in order to do so. ${ }^{5}$ Indeed, women worked long and difficult hours in often physically demanding jobs to ensure that their income would not be disrupted (McIntyre et al., 2011). Many women reported that they continued to work despite illness or physical exhaustion because if they did not, they would forgo income and consequently be unable to run their family and establish their children (McIntyre et al., 2011). Hoping to shield their children from a similar fate, women were preoccupied with ensuring their children received adequate education so that they would be able to work in a "good" job and earn sufficient income to "stand on their own." Nabanita (rural trader) explained:

I will make [my son] study even if I have to endure more hardship or have to spare my meal. If I can make him continue his study he will be established in the long run. I don't want him to suffer from the difficulties that I am going through now.

In addition, educating their daughters was believed to be important for securing a good marriage, sometimes without the need to pay a dowry, and if unsuccessful, would permit financial independence: "If children get more education then they can choose their own partner and they won't have to worry about dowry" (Labonya, garment worker). Ensuring that both daughters and sons received proper education was noted as particularly important - "The poor have many children; they go up step by step if they are provided with some education" (Orpita, garment worker).

While women strongly believed that establishing their children was their responsibility as mothers, they were also hopeful that their efforts would not be without future gain. Promita (agriculturalist) soberly explained, "I am bringing [my son] up by doing hardships now. If I am alive, my son will work to feed me. If I die, he'll at least bury me. We have our hope with the kids." We saw evidence that children accepted this expectation:

I told [my daughter], "You have read enough, you don't need to study anymore. Work for your living now." She replied, "I would work to feed you. Please, endure some hardship to help me continue my study. Then I would do some good job and make your meal." (Panchali, agriculturalist)

To summarize, women described a good life as one that permits them to maintain their reputation and honour by establishing their children through hardship and sacrifice. Through this, they hoped to secure a future for themselves, where their children would provide care for

\footnotetext{
${ }^{5}$ Although the Garo were not required to pay a dowry, a marriage feast was required of the family of the bride.
} 
their mothers when work was no longer possible. Similar findings have been reported by Wikan (1985), whose study of poor families in Cairo between 1969 and 1982 revealed that women directed significant efforts to educating their children, who would be able to acquire employment in offices and factories, rather than as domestics. Furthermore, women also anticipated support from their children in later life (Wikan, 1985). These aspirations developed within the context of material constraints, limited opportunities in accessing the labour market, gendered social norms, and an inadequate support system (McIntyre et al., 2011). The following section further explores aspirations and conceptualizations of wellbeing by examining the conditions and circumstances that thwart women from living a good life.

\subsection{Tensions: A quiet desperation}

Although women articulated conceptualizations of wellbeing, their sense of a good life was overtaken by pervasive feelings of hopelessness - a quiet desperation. Research by Avotri and Walters (1999) revealed a similar form of distress among Ghanaian women who described "worrying [and thinking] too much" (p. 1132) as an important occupational health hazard. The precariousness of their situation was evident as women reported that it affected their ability to sleep and eat. Liarae (garment worker) explained: "I'm worried about this. How will I manage my food for four people with such a small salary if I want to save money to help [my daughters get] married?" Certainly, the resources upon which women drew to manage their family and establish their children were limited, resulting in significant vulnerability to even minor disruptions (see also McIntyre et al., 2011). For example, when garment worker Devangi's rent increased along with the cost of food, she could no longer pay for childcare (200 taka [\$3 USD] per month) and her son had to stay home alone while she was at work. Many women were unable to send their children to school because they could not afford the cost of uniforms and ancillary fees; further, some children were needed at home to care for younger siblings, while others were fed at places of work. Joyeeta (rural trader) shared, "I can't send my son to school because he works in tea stall [and is fed two meals a day by the employer]."

In contrast to the expectation that older children would support their mothers, a number of women with working children described a collapse of their hope to be cared for by their children, thereby thwarting women's ability to achieve the conceptualization of wellbeing described above:

[My son] can't bear his own expenses. He has to give the house-rent and buy his food. He gets very low payment. He gets less than 3,000 taka. With this money he can hardly meet his own needs; how will he give me money? (Vijaya, Garo)

As a result of this quiet desperation, women commonly reported feeling constant mental anguish, which they called tension, from the time they woke up until they went to bed, with the latter being most often a time for reflection and worry:

[When I am alone] I contemplate on [things, like] that my kids do not suffer problems as I [have] suffered in my life [and] that their fate is not like mine. These thoughts come to my mind. I try to feel a little better. I pray to Allah, "Don't make my kids' fate like mine, so that they don't have to live in hardship." ... I can't sleep well at night for these types of tensions. I feel bad. I try to console myself. Then I stay lying on the bed. (Jayashri, agriculturalist)

At times, this tension prevented women from working and earning an income to run their family. Chumi (garment worker) explained, "I am mentally weak. Why? Because of my kids. Suppose if something very bad happens to my life; where will my kid get shelter then? ... I 
miss office for the pain." The Garo women, who typically had more children, minimal opportunities for employment, little to no land, and poor access to healthcare and education for their children were most vulnerable and consequently most sombre:

There are so many tensions. We don't have our own house as well as land.... I don't have rice. ... In the rainy season I get drenched working in the field. Returning home, I get wet again as the thatched roof of my house is broken. How will I find peace? ... I feel so panicked; my heartbeats go faster. People may die if they keep on thinking this way. They may get peace only after their death. I keep thinking of these things, too. (Rani, Garo)

While their faith and belief in fate helped temper women's anxiety and tension over their desperate situations somewhat ("Allah helps us pass our days [when we feel anxious]" [Bani, urban trader]), the shame women felt regarding their condition was palpable: "I cover my whole body with burka keeping my eyes exposed only while I go out of my house so that none can recognize me because I feel ashamed of my poor condition" (Bhavani, subsistence agriculturalist). Upon hearing that the research team would share the findings with government representatives, Brinda (agriculturalist) exclaimed:

If the government could provide a house and even if I would die under the wrecks of my own house along with my kids after such laborious work, I would be grateful to Allah [crying].

Her emotional response shows how painful it was to even contemplate a better life.

Suicide was the most extreme reaction to tensions and was mentioned by three women. It would be disingenuous, however, to attribute women's anguish, "forms of distress that are linked with the material and social circumstances of [women's] lives" (Avotri \& Walters, 1999, p. 1125), to symptoms of depression or poor mental health given the deep vulnerability in which they lived their lives.

I think about how I can put my home in order, how to bring up my kids and so on. ... When these thoughts come to my mind, I don't know what to do. Then I wish I could die by taking poison. But again I think if I die who will take care of my kids then. When I think about these facts I can't sleep the whole night. When I worry too much I can't take my food. And I feel sick then. (Rekha, Garo)

\section{Discussion}

"I am human being; I am a mother. What will I say? I have no other identity" (Bhavani, agriculturalist). In seeking to understand what wellbeing and a good life means to ultra-poor women, it is evident that women prioritize their children above themselves and aspire primarily to be good mothers and honourable women. While the notion of maternal sacrifice, especially among the poor, is well-described (Dasgupta, 1995), our findings add to this literature by demonstrating how ultra-poor women endure physical and emotional hardship and sacrifice their own personal aspirations, happiness, nutrition, and health in order to care for and establish their children. In so doing, they maintain their reputation as an honourable woman and a good mother (i.e., one who sacrifices for her children) and thus hope that their children, both male and female, will, to the best of their abilities, care for them in their old age.

For the ultra-poor women in this study, being an honourable woman and good mother surfaced as one of the only facets of their lives they could control, especially within the patriarchal constraints of Bangladeshi society. Women report drawing considerable comfort from their spirituality in times of stress, whether they were Muslim, Hindu, or Christian, which 
stands in contrast to discourse that emphasizes religion, and Islam in particular, as disempowering (White, 2010b). Although an in-depth exploration of the role of religion and spirituality in women's lives is beyond the scope of this paper, attention to its role as a refuge in times of distress and powerlessness lends support to recent scholarship that rejects the notion that religion is simply "the antithesis to "women's empowerment" and instead aims to understand religious actors on their terms (White, 2010b, p. 358). As Deeb (2006) succinctly noted: "[Faith] is a very real thing in and of itself, located in practices, discourse, inner and outer states, relationships, and effects in the world" (p. 40).

All women in our study articulated conceptions of personal wellbeing that were inextricably linked to their children, and personal fulfilment acquired by remaining honourable was contingent primarily on their behaviours as mothers rather than as individuals. It seems that women tend to view themselves not as "ends in their own right," (Nussbaum, 2000, p. 6), but instead "as mere instruments of the ends of others - reproducers, caregivers, sexual outlets, agents of a family's general prosperity" (Nussbaum, 2000, p. 2). Again and again, women demonstrated in their interviews and through their narratives that they rarely do anything to improve their wellbeing as individuals: food given in recognition of their participation in the study was given to their children, and charity received during Eid or other occasions was used almost exclusively to buy food and clothing for their children.

Thus, while women manage to more or less get through their days, driven by the desire to establish their children today and secure their wellbeing in the future, this is contingent on a deeply ingrained social expectation of self-sacrifice, which is "a far cry from activities that would promote her own well-being" (Dasgupta, 1995, p. 59). Douglas and Ney (1998) have pointed out that:

Expectations that women or the old should place their own well-being, or even their survival, after that of the family are internalized to such an extent that the liberal criteria of injustice are not applicable: These people are neither forced nor do they necessarily dislike their social responsibilities. Well-being is not necessarily synonymous with fulfilment of private desires. (pp. 69-70)

Thus, if the goal is to enhance development efforts for ultra-poor women through an in-depth examination of their aspirations and perceptions of wellbeing, should we rely on these accounts if they are conceptualized within deeply ingrained social expectations of self-sacrifice? As Nussbaum (2000) accurately explains,

Even when women appear to be satisfied with such customs [i.e., female deference] we should probe more deeply. Women's development groups typically encounter resistance initially, because women are afraid that change will make things worse. (pp. 42-43)

The ESRC-WeD group has acknowledged that tensions exist with regards to resources, capabilities, and opportunities that enable goals beyond what is possible at the local level (Gough, 2004). In presenting and exploring ultra-poor women's daily aspirations, i.e., focusing on "what is positive and desirable [at a local level] ... rather than what is lacking or negative [at a universal level]" (Wellbeing \& Poverty Pathways, 2011, p. 2), we do not intend to imply that ultra-poor women would not require and personally benefit from access to basic needs such as healthcare, autonomy, security, and even increased income, which are commonly cited in the 
development literature (see for example, Doyal \& Gough, 1991). ${ }^{6}$ Certainly, these women are so poor that any untied financial assistance would go a long way in alleviating much of their insecurity (for more on this, see McIntyre et al., 2011). As Clark (2002) reminds us, "the success of economic development does ultimately have to be judged in terms of its consequences for human beings" (p. 6).

Thus, understanding women's aspirations and the local context in which they live their lives will help to determine how to best allocate program resources and efforts to ultimately positively impact their wellbeing. Nussbaum (2000), as well as Wood (2003), have argued that social policy, rather than being applied universally, must be designed to meet the specific needs of those for whom the policy is intended. This point is further developed by White and Ellison (2007, p. 163), who question the effectiveness of adult education programs, which are common in development, when those who receive the training do not have an opportunity to put this learning into practice in their daily lives, a point that actually surfaced in women's narratives when the most highly educated woman in the study explained: "Is [class] six really enough? That's not a lot...also I have never managed in exams to get other skills" (Lili, Garo).

From our findings, what is needed most for this group of ultra-poor women to achieve a good life is employment opportunities that respect basic labour standards and that would enable women to earn an income that can provide for the household's basic needs; accessible, quality schooling and childcare for their children; basic affordable healthcare; and an end to corruption (e.g., dowry, bribing, etc.) (McIntyre et al., 2011). Only once these are achieved or perceived as within their reach can women's focus turn inward to their personal wants, desires, and aspirations. These might be as modest as Joyeeta's observation that other women had blankets and beds ("I see people [who have] quilts and mattresses ... That one day I will sleep very comfortably in my bed is my only dream") to women, once 'lifted out of poverty,' focusing on their own education, tackling new business opportunities, or even leisurely pursuits, i.e., things that bring joy and satisfaction to their lives.

When we situate our findings (see also McIntyre et al., 2011; McIntyre \& Munro, 2013; Watterson, McIntyre, \& Rondeau, in press) within the context of Whole Person Development, numerous leverage points for addressing the wellbeing of ultra-poor women who are heads of household emerge. Given women's propensity to put their children's needs before their own, social programs and policies that aim to assist women who have children must consider how they can provide assistance that will benefit women directly without asking them to withhold assistance from their children. For example, food relief and feeding programs for women delivered at their homes and at their place of work and the elimination of bureaucratic and corrupt barriers that reduce household income would directly benefit women and subsequently enable them to care for their children and participate more fully in their family life. To increase their income, petty traders require small bursaries that are not bound by the high interest rates of microcredit schemes to increase their sales volumes; garment workers who languish in sub-contractor shops deserve protection of their labour rights, the opportunity to pursue job advancement, and employment in better workplaces that are part of the formal economy where such rights are monitored and work-related training may occur; and women agriculturalists who function as share-croppers require grants and low-interest loans to fund

\footnotetext{
${ }^{6}$ Nussbaum (2000) has succinctly argued that, "[It] is one thing to say that we need local knowledge to understand the problems women face, or to direct our attention to some aspects of human life that middle-class people tend to take for granted. It is quite another matter to claim that certain very general values such as the dignity of the person, the integrity of the body, basic political rights and liberties, basic economic opportunities, and so forth, are not appropriate norms to be used in assessing women's lives in developing countries." (p. 41)
} 
their crops, similar to the agricultural subsidies offered to the farm owners from whom they lease the land (see Watterson et al., in press). Finally, education or training that would typically be delivered in livelihood programs (e.g., financial and entrepreneurial skills) could be delivered to women in ways that would complement rather than compete with their employment and income generation activities.

In addition, small adjustments or modifications to development initiatives and programs that already exist can be made to more effectively address the wellbeing of ultra-poor women who are heads of household. For example, group-based development initiatives (e.g., women's cooperative programs or self-help groups) that aim to address poverty and enhance economic wellbeing of women must "examine and understand the performance of these forms of group entrepreneurship from a social point of view in order to locate them within a broader social and policy context" (Torri, 2012, p. 59). That is best achieved by considering the views and interest of the women themselves. Power struggles, illiteracy, overdependence on leaders, gender roles outside the group, social pressures from other group participants, and the financing of activities with low economic return are some reasons that group-based initiatives have failed ultra-poor women (Torri, 2012). The investigation and facilitation of different group configurations that might naturally occur among ultra-poor women (e.g., by occupation, age, number of children, location of residence) and less restrictive rules and instruments might lead to the creation of cooperatives that are more useful and effective for the delivery of development initiatives.

Microcredit programs, often touted as an exemplar in assisting ultra-poor women, would be of greater utility if they were adapted to the specific needs of such women. Walker and Matin (2006) have suggested that programs such as Challenging the Frontiers of Poverty Reduction/Targeting the Ultrapoor (CFPR/TUP) should consider reviewing the terms of their savings rules so that funds can be legitimately used towards unmet needs, rather than only for business-related purchases. Pretes (2002) has argued that microequity financing (i.e., shares or profit are not expected by investors) of development initiatives through the provision of startup funds for the very poor are preferable to microcredit programs. Thus, a graduated system might be considered: women who are not credit worthy would first be eligible for a living and basic needs stipend in addition to a bursary that could be used to invest in their business, increase profits, and generate additional income. The additional income could allow such women to then graduate to a loan-based program. Such a system would have a significant impact on the women's ability to meet basic needs and aspirations, with the ultimate goal of achieving their modest conceptualizations of wellbeing.

Finally, the development of monitoring systems for non-governmental organizations and government social safety-net programs that would permit the identification of who is not accessing these programs would be an important step in understanding the adjustments that are needed to enhance access to such programs by this population group.

\section{Conclusion}

In 2000, Nussbaum asserted, "Women, in short, lack essential support for leading lives that are fully human" (p. 4), and this remains the case for millions of women living in conditions similar to those of our participants. The burgeoning body of research on happiness, subjective wellbeing, and hedonic psychology (e.g., Kahneman et al., 1999) and the direct measurement of values, aspirations, and happiness/unhappiness (Camfield et al., 2009) suggest that it is not so farfetched to consider living less desperate lives as an outcome of development activities. In other words, efforts could be directed towards localized visions of wellbeing, which are often more 
moderate and thus more attainable than global aspirations, but which nonetheless have the potential to significantly improve the wellbeing of many. Although policymakers may be more familiar and comfortable with aggregate statistics to support development (Camfield et al., 2009), a reconstruction of development to consider wellbeing and a Whole Person Development approach demonstrates that there are in fact many ways to intervene and effect meaningful improvements in the lives of ultra-poor women.

\section{Authors \\ Lynn McIntyre \\ University of Calgary \\ lmcintyr@ucalgary.ca \\ Krista Rondeau \\ University of Calgary \\ Publishing Timeline}

Received 27 August 2012

Accepted 14 January 2013

Published 7 March 2013

\section{References}

Ahmed, S. M., Petzold, M., Kabir, Z. N., \& Tomson, G. (2006). Targeted intervention for the ultra poor in rural Bangladesh: Does it make any difference in their health-seeking behaviour? Social Science and Medicine, 63, 2899-2911. http://dx.doi.org/10.1016/j.socscimed.2006.07.024

Alkire, S. (2010). Human development: Definitions, critiques, and related concepts. United Nations Development Programme. http://www.ophi.org.uk/human-development-definitions-critiques-andrelated-concepts

Appadurai, A. (2004). The capacity to aspire: Culture and the terms of recognition. Stanford: Stanford Social Sciences.

Attride-Stirling, J. (2001). Thematic networks: An analytical tool for qualitative research. Qualitative Research, 3, 385-405. http://dx.doi.org/10.1177/146879410100100307

Avotri, J. Y. \& Walters, V. (1999). "You just look at our work and see if you have any freedom on earth": Ghanaian women's accounts of their work and their health. Social Science and Medicine, 48, 1123-1133. http://dx.doi.org/10.1016/S0277-9536(98)00422-5

Bal, E. (2007a). They ask if we eat frogs: Garo ethnicity in Bangladesh. Pasir Panjang, Singapore: Institute of Southeast Asian Studies Publishing.

Bal, E. (2007b). Becoming the Garos of Bangladesh: Policies of exclusion and the ethnicisation of a 'tribal' minority. South Asia: Journal of South Asia, 30, 439-455. http://dx.doi.org/10.1080/00856400701714062

Ben-Ari, A. \& Enosh, G. (2010). Processes of reflectivity: Knowledge construction in qualitative research. Qualitative Social Work, 10, 152-171. http://dx.doi.org/10.1177/1473325010369024

Biswas-Diener, R. \& Diener, E. (2001). Making the best of a bad situation: Satisfaction in the slums of Calcutta. Social Indicators Research, 55, 329-352. http://dx.doi.org/10.1023/A:1010905029386

Borkan, J. (1999). Immersion/crystallization. In B. F. Crabtree and W. L. Miller (Eds.), Doing qualitative research (2nd ed., pp. 179-194). Thousand Oaks, California: Sage.

Bryman, A. (2004). Social research methods (2nd ed.). Oxford: Oxford University Press.

Camfield, L., Crivello, G., \& Woodhead, M. (2009). Wellbeing research in developing countries:

Reviewing the role of qualitative methods. Social Indicators Research, 90, 5-31.

http://dx.doi.org/10.1007/s11205-008-9310-z

Chambers, R. (1997). Whose reality counts? Putting the first last. India: ITDG Publishing. 
Clark, D. A. (2002). Visions of development: A study of human values. Northampton, MA: Edward Elgar Publishing.

Commission on Social Determinants of Health. (2008). Closing the gap in a generation: Health equity through action on the social determinants of health. Final report of the Commission on Social Determinants of Health. http://whqlibdoc.who.int/publications/2008/9789241563703_eng.pdf

Dasgupta, P. (1995). An inquiry into well-being and destitution. Oxford: Oxford University Press. http://dx.doi.org/10.1093/0198288352.001.0001

Deeb, L. (2006). An enchanted modern: Gender and public piety in Shi'i Lebanon. Princeton: Princeton University Press.

Douglas, M. \& Ney, S. (1998). Missing persons: A critique of the social sciences. Berkeley and Los Angeles, CA: University of California Press.

Doyal, L. \& Gough, I. (1991). A theory of human needs. London: Macmillan.

Geertz, C. (1973). The interpretation of cultures. New York, NY: Basic Books.

Gough, I. (2004). Human well-being and social structures: Relating the universal and the local. Global Social Policy, 4, 289-311. http://dx.doi.org/10.1177/1468018104047489

Gough, I. \& McGregor, J. A. (2007). Wellbeing in developing countries: From theory to research. Cambridge: Cambridge University Press. http://dx.doi.org/10.1017/CBO9780511488986

Graneheim, U. H. \& Lundman, B. (2004). Qualitative content analysis in nursing research: Concepts, procedures and measures to achieve trustworthiness. Nurse Education Today, 24, 105-112. http://dx.doi.org/10.1016/j.nedt.2003.10.001

Halder, S. R. \& Mosley, P. (2004). Working with the ultra-poor: Learning from BRAC experiences. Journal of International Development, 16, 387-406. http://dx.doi.org/10.1002/jid.1084

Hsieh, H.-F. \& Shannon, S. E. (2005). Three approaches to qualitative content analysis. Qualitative Health Research, 15, 1277-1288. http://dx.doi.org/10.1177/1049732305276687

Ibrahim, S. (2011). Poverty, aspirations, and well-being: Afraid to aspire and unable to reach a better life - voices from Egypt. Brooks World Poverty Institute Working Paper No. 141. http://papers.ssrn.com/sol3/papers.cfm?abstract_id=1747798

Kabeer, N. (2004). Snakes, ladders and traps: Changing lives and livelihoods in rural Bangladesh (19942001). CPRC Working Paper 50, Chronic Poverty Research Centre. http://www.prcpbbids.org/documents/workingpaper/wp9-full\%20text.pdf

Kahneman, D., Diener, E., \& Schwarz, N. (1999). Well-being: The foundations of hedonic psychology. New York: Russell Sage Foundation.

Klugman, J. (2010). The real wealth of nations: Pathways to human development. Human Development Report 2010, United Nations Development Programme. http://hdr.undp.org/en/media/HDR_2010_EN_Complete_reprint.pdf

Lincoln, Y. S. \& Guba, E. G. (1985). Naturalistic inquiry. Beverly Hills, CA: Sage.

Matin, I., Sulaiman, M., \& Rabbani, M. (2008). Crafting a graduation pathway for the ultra poor: Lessons and evidence from a BRAC programme. Working Paper No. 109, Chronic Poverty Research Centre, BRAC Research and Evaluation Division. http://www.chronicpoverty.org/uploads/publication_files/WP109_Martin.pdf

McGregor, J. A. (2004). Researching well-being: Communicating between the needs of policy makers and the needs of people. Global Social Policy, 4, 337-358. http://dx.doi.org/10.1177/1468018104047491

McGregor, J. A., McKay, A., \& Velazco, J. (2007). Needs and resources in the investigation of well-being in developing countries: Illustrative evidence from Bangladesh and Peru. Journal of Economic Methodology, 14, 107-131. http://dx.doi.org/10.1080/13501780601170115

McIntyre, L., Rondeau, K., Kirkpatrick, S., Hatfield, J., Islam, K. S., \& Huda, S. N. (2011). Food provisioning experiences of ultra poor female heads of household living in Bangladesh. Social Science and Medicine, 72, 969-976. http://dx.doi.org/10.1016/j.socscimed.2011.01.011

McIntyre, L. \& Munro, J. (2013). Nobody helps us: Insights from ultra poor Bangladeshi women on being beyond reach. Development in Practice. 23, 2, 230-240. 
Moss, N. E. (2002). Gender equity and socioeconomic inequality: A framework for the patterning of women's health. Social Science and Medicine, 54, 649-661. http://dx.doi.org/10.1016/S02779536(01)00115-0

Nussbaum, M. (2000). Women and human development: The capabilities approach. Cambridge: Cambridge University Press. http://dx.doi.org/10.1017/CBO9780511841286

Pretes, M. (2002). Microequity and microfinancing. World Development, 30, 1341-1353. http://dx.doi.org/10.1016/S0305-750X(02)00044-X

QSR International. (2010). NVivo [computer software]. Doncaster, Australia: QSR International Pty Ltd.

Rahman, H. Z. \& Hossain, M. (1995). Rethinking rural poverty: Bangladesh as a case study. New Delhi: Sage.

Rashid, S. F. (2006). Emerging changes in reproductive behaviour among married adolescent girls in an urban slum in Dhaka, Bangladesh. Reproductive Health Matters, 14, 151-159. http://dx.doi.org/10.1016/S0968-8080(06)27221-5

Robeyns, I. (2005). The capability approach: A theoretical survey. Journal of Human Development and Capabilities, 6, 93-117. http://dx.doi.org/10.1080/146498805200034266

Robeyns, I. (2006). The capability approach in practice. The Journal of Political Philosophy, 14, 351-376. http://dx.doi.org/10.1111/j.1467-9760.2006.00263.x

Sen, A. (1999). Development as freedom. New York, NY: Knopf.

Silverman, D. (2006). Interpreting qualitative data (3rd ed.). London: Sage.

Torri, M. C. (2012). Community gender entrepreneurship and self-help groups: A way to forward to foster social capital and truly effective forms of participation of rural poor women? Community Development Journal, 47, 58-76. http://dx.doi.org/10.1093/cdj/bsq019

Walker, S. \& Matin, I. (2006). Changes in the lives of the ultra poor: An exploratory study. Development in Practice, 16, 80-84. http://dx.doi.org/10.1080/096145205004500450917

Watterson, R., McIntyre, L., \& Rondeau, K. (in press). A case of gendered hazards and health effects for ultra-poor women. In D. Figart and T. Warnecke (Eds.), Handbook of Research on Gender and Economic Life.

Wellbeing and Poverty Pathways. (2011). An integrated model for assessing wellbeing. Briefing No. 1. http://www.dfid.gov.uk/R4D/Output/186450/Default.aspx

Wellbeing Research in Developing Countries. (n.d.) Current work on wellbeing at Bath. http://www.welldev.org.uk/wed-new/index.html

White, S. C. (2010a). Analysing wellbeing: A framework for development practice. Development in Practice, 20, 158-172. http://dx.doi.org/10.1080/09614520903564199

White, S. C. (2010b). Domains of contestation: Women's empowerment and Islam in Bangladesh. Women's Studies International Forum, 33, 334-344. http://dx.doi.org/10.1016/j.wsif.2010.02.007

White, S. \& Ellison, M. (2007). Wellbeing, livelihoods and resources in social practice. In I. Gough and J. A. McGregor (Eds.), Wellbeing in developing countries: From theory to research (pp. 157-175). Cambridge: Cambridge University Press.

Wikan, U. (1985). Living conditions among Cairo's poor - a view from below. The Middle East Journal, 39, 7-26.

Wood, G. (2003). Governance and the common man: embedding social policy in the search for security. In P. Mosley and E. Dowler (Eds.), Poverty and social exclusion in north and south: Essays on social policy and global poverty reduction (pp. 83-121). London: Routledge. 